\title{
Balance, General Cognition and Lower Motoric Strength in Elderly: Tai Chi Versus Brisk Walking
}

\author{
Steven Kelvin Anam, ${ }^{1}$ Yuni S. Pratiwi, ${ }^{2}$ Marina A. Moelino ${ }^{3}$ \\ ${ }^{1}$ Faculty of Medicine Universitas Padjadjaran, ${ }^{2}$ Department of Anatomy, Cell Biology and \\ Physiology Faculty of Medicine Universitas Padjadjaran, ${ }^{3}$ Department of Physical Medicine and \\ Rehabilitation Faculty of Medicine Universitas Padjadjaran/Dr. Hasan Sadikin General Hospital \\ Bandung
}

\begin{abstract}
Background: The number of elderly in Indonesia continues to increase. A better quality of life can be achieved by preventing reduction of elderly's cognition, balance and strength of the lower extremities. Tai Chi has been suggested as one of the sports to maintain cognition, balance and lower extremity strength for elder people. However, there are still few studies that compare Tai Chi to other exercises. The aim of this study was to compare the effects of practicing Tai Chi verrsus brisk walking.

Methods: The study design was observational, cross-sectional. Elderly who practiced Tai Chi and Briskwalk in Tegalega sport field were chosen as the target population. The respondents must be at least 60 years old, no history of cardiovascular disease in the last 3 months, no musculoskeletal complaints, no obvious signs and symptoms of chronic diseases. Afterwards, the respondents were examined using Timed Up and Go (TUG) Test for balance, Montreal Cognitive Assessment (MoCA) for cognition and leg dynamometer for the lower extrimities strength. The collected data was analyzed using Mann-Whitney statistical test and Kolmogorov-Smirnov test.
\end{abstract}

Results: No significant difference was detected among the three parameters between Tai Chi group (TCG) and Brisk Walking group (BWG). Difference of $0.5(\mathrm{p}=0.314)$ and $0.6(\mathrm{p}=0.554)$ was found for TUG Test and MoCA Test between TCG and BWG using Mann Whitney. The leg dynamometer was tested using Kolmogorovsmirnov $(\mathrm{p}=1.00)$.

Conclusions: Similar result of balance, cognition, and lower motor strength are found between TCG and BWG.

Keywords: Brisk walking, balance, cognition, lower motor strength, Tai Chi

\section{Introduction}

Life expectancy is increasing in Indonesia, with the number of elderly people in Indonesia is going to reach $11.34 \%$ in $2020{ }^{1}$ This increasing number of elderly could lead to an increasing dependency and decreasing quality of life of the population. ${ }^{2}$ To prevent the decreasing quality of life in elders, there are several factors, known as the geriatric giants that need to be improved. The geriatric giants are factors that can be modified to prevent other disability, among which that the writers choose cognition, postural stability, and risk of fall. ${ }^{3}$ The improvements of these 3 giants can be achieved by multi-sensorial exercise (including balance, proprioceptive, and position changing) and lower extremity strength. ${ }^{4}$ One of the sports that is considered fit for the elderly is Tai Chi.

Tai Chi is a "mind-body" exercise, in which the participants have to do repetitive movements, perform slowly with many postural changes. From several studies, it is known that Tai Chi increases strength of the lower extremities significantly. ${ }^{5}$ Tai Chi also improves the cognitive function. 6,7 Tai Chi improves balance, as shown by the Timed Up and Go (TUG) Test. ${ }^{8}$ However, studies that compare Tai Chi to other moderate exercises are still rare. Therefore, the purpose of this study was to compare the balance, cognition, and lower extremities strength between elderly who practice Tai Chi and elderly who

Correspondence: Steven Kelvin Anam, Faculty of Medicine, Universitas Padjadjaran, Jalan Raya Bandung-Sumedang Km.21, Jatinangor, Sumedang, Indonesia, Phone: +628395454808 Email: stevenanam1993@gmail.com 
exercise with brisk walking.

\section{Methods}

The study was carried out on August until
November 2014 in one of sport centers (Tegalega Sports Center) in Bandung, West Java, Indonesia. The study was approved by the ethical comittee. The study design used was non-experimental, observational, crosssectional.

Table 1 Baseline Characteristics Two Groups

\begin{tabular}{|c|c|c|}
\hline & Tai Chi, $n=42$ & Brisk Walking, $n=47$ \\
\hline \multicolumn{3}{|l|}{ Sex } \\
\hline Male & $10(24 \%)$ & 14 (30\%) \\
\hline Female & $32(76 \%)$ & $32(70 \%)$ \\
\hline \multicolumn{3}{|l|}{ Education } \\
\hline No education & $1(2 \%)$ & $0(0 \%)$ \\
\hline SD (Elementary School) & $8(19 \%)$ & $9(19 \%)$ \\
\hline SMP (Junior High School) & $14(33 \%)$ & $15(33 \%)$ \\
\hline SMA (Senior High School) & $17(41 \%)$ & $17(37 \%)$ \\
\hline D3 & $1(2 \%)$ & $1(2 \%)$ \\
\hline S1 & $1(2 \%)$ & $4(9 \%)$ \\
\hline \multicolumn{3}{|l|}{ Income level } \\
\hline No information & $3(7 \%)$ & $10(22 \%)$ \\
\hline$<$ Rp2.000.000,00 & $21(50 \%)$ & $17(37 \%)$ \\
\hline Rp 2.000.000,00- Rp 4.000.000,00 & $12(29 \%)$ & $11(24 \%)$ \\
\hline$>$ Rp4.000.000,00 & $6(14 \%)$ & $8(17 \%)$ \\
\hline \multicolumn{3}{|l|}{ Other sports } \\
\hline No other sports & $21(50 \%)$ & $28(61 \%)$ \\
\hline Light intensity & $1(2 \%)$ & $0(0 \%)$ \\
\hline Medium intensity & $12(29 \%)$ & $6(13 \%)$ \\
\hline High intensity & $8(19 \%)$ & $12(26 \%)$ \\
\hline \multicolumn{3}{|l|}{ Past Medical History } \\
\hline Stroke & $1(2 \%)$ & $2(4 \%)$ \\
\hline Epilepsy & $0(0 \%)$ & $1(2 \%)$ \\
\hline Central Nervous System Infection & $0(0 \%)$ & $1(2 \%)$ \\
\hline Diabetes & $4(10 \%)$ & $8(17 \%)$ \\
\hline Gout & $9(21 \%)$ & $9(20 \%)$ \\
\hline Hipertension & $17(41 \%)$ & $18(39 \%)$ \\
\hline $\begin{array}{l}\text { Chronic Obstructive Pulmonary } \\
\text { Disease }\end{array}$ & $1(2 \%)$ & $1(2 \%)$ \\
\hline Asthma & $1(2 \%)$ & $1(2 \%)$ \\
\hline Angina Pectoris & $0(0 \%)$ & $1(2 \%)$ \\
\hline Sprain & $5(12 \%)$ & $1(4 \%)$ \\
\hline
\end{tabular}

Note: * all the diseases happened in the past and were well controlled in the last 3 months, **the disease not writed in the table means both groups' number is 0 
Table 2 Hypothesis testing for TUG Test and MoCA Test

\begin{tabular}{lccc}
\hline & $\mathbf{n}$ & Median & $\mathbf{p}$ \\
\hline TUG Test & & & 0.314 \\
Tai Chi Group & 42 & $7.58(5.06-13.13)$ & \\
BriskWalk Group & 46 & $7.62(5.50-11.87)$ & 0.554 \\
MoCA Test & & & \\
Tai Chi Group & 42 & $24(10-30)$ & \\
BriskWalk Group & 46 & $23.5(13-30)$ & \\
\hline
\end{tabular}

Ahundredand elevenelderlywhoperformed their sport activites in Tegalega were recruited. The elders must be practicing either Tai Chi or Brisk Walking. The respondents were asked whether they agreed or not to participate in the test and informed consent was given. Exclusion, inclusion and various confounding variables (age, sex, years of education, income, the frequency and duration of training, and whether there was other exercise other than Tai Chi/Brisk Walking, and history of diseases [stroke, alzheimer, epilepsy, CNS infection, diabetes, gout, hypertension, emphysema and chronic obstructive pulmonary disease, Asthma, myocardial infarct, angina pectoris, hypertensive heart disease, heart failure, osteoarthritis, rheumatic, Myasthenia Gravis, Myopathy, spraint]) were asked. Uncontrolled chronic disease, osteoarthritis, alzheimer and history of hospitalization in the last 3 months were excluded. The minimum duration of Tai Chi/Brisk walking practice must be at least 6 months. The candidates must walk without assistance of walking aids. Subjects who had met the criteria were given the TUG Test, Indonesian Montreal Cognitive Assessment (MoCA) for cognition and leg dynamometer. The outcome of TUG test was numerical. TUG Test time more than 14 seconds was excluded , due to possibility of balance disorders. The Indonesian MoCA Test was reliable, with scale from 0-30 as the result.9 The leg dynamometer test was done according to the standard procedure, knee bended to 130 degrees and fixation to ensure that only the legs are used. The result of the leg dynamometer test was divided into 3 categories. The first category was $-1 \mathrm{SD}$ of the mean through mean. The second category was mean until +1 SD. The third category was +1 SD until +2 SD from the mean. The data were collected by 13 people, and all had been standardized before the study, with each of the tests was done only using certain people.

TUG Test is accounted to evaluate balance because of its easy to practice, reliability and validity. ${ }^{3,10}$ MoCA test as a cognition assesment is usually used because it encompasses a large aspect of cognition, and the test is valid to be use linearly. ${ }^{11}$

The sample size calculation based on the previous study using analytical, one tailed studies of unpaired-continuous variable sample calculation was 42 per group. ${ }^{12}$ The final calculation of the sample size was $46(10 \%$ is added). Continuous variables were then summarized as mean \pm SD. The difference in mean of TUG Test and MoCA test was analyzed first using normality test (Shapiro-Wilk). Then tested using Mann-Whitney test, because the data was not normally distributed. The leg dynamometer measurement was calculated using Kolmogorov-Smirnov. All the statistics analysis was generated using a statistical

Table 3 Hypothesis testing for Leg dynamometer

\begin{tabular}{lcccc}
\hline & \multicolumn{3}{c}{ Leg Dynamometer } & \multirow{2}{*}{$\mathbf{p}$} \\
\cline { 2 - 4 } & $\mathbf{- 1 \text { SD - Mean }}$ & Mean - 1 SD & $\mathbf{1 ~ S D ~ - ~ 2 ~ S D ~}$ & \\
\cline { 2 - 4 } & $\mathbf{n ~ ( \% )}$ & $\mathbf{n ~ ( \% )}$ & $\mathbf{n ~ ( \% ) ~}$ & 1.000 \\
TCG & $26(61.9)$ & $12(28.6)$ & $4(9.5)$ & \\
BWG & $31(67.4)$ & $11(23.9)$ & $4(8.7)$ & \\
Total & $57(64.8)$ & $23(26.1)$ & $8(9.1)$ & \\
\hline
\end{tabular}


program. The tested data was not normally distributed.

\section{Result}

Of 62 people who practiced Tai Chi (TCG), 11 were excluded because of stopping from the exercise in the last 3 months, 6 were excluded because of certain diseases they had, 2 were dropped due to not being able to finish the tests, 1 was additionally dropped because the data was too extreme, and 42 were included in the study. From 49 people in the Brisk Walking Group (BWG) who agreed to participate, 1 was excluded because of not exercising at the last 3 months, 2 was dropped because the data was too extreme, and 46 were included in the study.

Mean age was $68.4 \pm 5.4$ in TCG, $66.1 \pm 5.6$ in BWG. Frequencies of training in hour/week was $319.8 \pm 149.8$ in TCG, $307.4 \pm 149.7$ in BWG. The minimum duration for TCG was 11.9 \pm 8.5 years of practice, and BWG was $10.8 \pm 10.9$ years of exercise. The characteristics between the TCG and BWG were not significantly different, except age $(Z=-2.162, p=0.031)$. However, age was confounding only for TUG Test, because it was only significant when correlated with TUG Test $(0.263, \mathrm{p}=0.013)$.

The significance of TUG Test, MoCA Test, leg dynamometer were all above 0.05. The regression test was not done because all the $p$ value for all the three dependent variable is above 0.25 .

\section{Discussion}

There were other studies about Tai Chi and cognition that contradicts this study. Lam et al. ${ }^{6}$ (2012) found less decreament in cognitive decline in elders. However the control group were given only stretching exercises, with no aerobic exercise. ${ }^{6}$ Tai Chi and brisk walking both are moderate intensity aerobic nature, giving the same result in this study. Tai Chi is also thought to increase cognition because of the crossing the midline movements. There are some support and contradiction of this theory, so that the theory is still debatable, and can not be used reliably. ${ }^{13}$ One of the contributors to balance is proprioception. Tsang and HuiChan ${ }^{14}$ found better joint sense and balance in elders practicing Tai Chi than those practicing golf. However, in another study, Tai Chi and brisk walking intervention both increase the proprioception of the participants. ${ }^{15}$ The result is even greater in Brisk Walking group..$^{15}$ The increament of balance, if it is based on this previous study, should be similar between the two groups..$^{15}$ The recent study found no difference in increament of strength between the two groups. ${ }^{16}$

This study had limitations. The result of TUG Test in this study was confounded by age, which are not controlled in this study (continuous numerical type of data). The overall mean of the cognition both in TCG or BWG is low $(23.77 \pm 3.89$, even after adjustment with years of education +1 for 10-12 years of education, +2 for 4-9 years of education). ${ }^{17}$ This phenomenon can be related with the language used. The majority of the respondents attended primary mandarin school and have very little Indonesia language vocabularies, lowering scores on some questions. Last, there was only one Tai Chi teacher for each session which was attended by around 40-50 practitioner. Therefore, lack of supervision can be the reason why the results of the exercise, including the lower extremities strength, were not optimal for the TCG. Some potentially related variables (other sports, socioeconomstudy method should also be experimental to control the exposure of the exercises. Our study conclusion is that TCG have similar cognition, balance, and strength of lower extremities to BWG.

\section{References}

1. Santika A. Lanjut usia dalam perspektif hukum dan HAM. Buletin Jendela Data dan Informasi Kesehatan. 2013;1:29-32.

2. Pusat Data dan Informasi Kementerian Kesehatan Republik Indonesia. Gambaran kesehatan lanjut usia di Indonesia. Buletin Jendela Data dan Informasi Kesehatan. 2013;1:1-18.

3. Misiaszek BC. Geriatric medicine survival handbook. Revised Ed. Hamilton, Ontario: Michael G. DeGroote School of Medicine McMaster University; 2008. p.26.

4. Alfieri FM, Riberto M, Gatz LS, Ribeiro CPC, Lopes JAF, Santarém JM, et al. Functional mobility and balance in communitydwelling elderly submitted to multisensory versus strength exercises. Clin Interv Aging. 2010;5:181-5.

5. Kuramoto AM. Therapeutic benefits of Tai Chi exercise: research review. Wis Med J. 2006;105(7):40-3.

6. Lam LC, Chau R, Wong BM, Fung AW, Tam $\mathrm{CW}$, Leung GT, et al. A 1-year randomized controlled trial comparing mind body exercise (Tai Chi) with stretching and toning exercise on cognitive function in older Chinese adults at risk of 
cognitive decline. J Am Med Dir Assoc. 2012;13(6):568.e15-20.

7. Kasai JYT, Busse AL, Magaldi RM, Soci MA, de Moraes Rosa P, Curiati JAE, et al. Effects of Tai Chi Chuan on cognition of elderly women with mild cognitive impairment. Einstein (São Paulo). 2010;8(1):40-5.

8. Konig PR, Galarza E, Goulart NBA, Lanferdini FJ, Tiggeman CL, Dias CP. Effects of Tai Chi Chuan on the elderly balance: a semi-experimental study. Rev Bras Geriatr Gerontol. 2014;17(2):373- 81.

9. Husein N, Lumempouw S, Ramli Y, Hequtanto. Uji validitas dan reliabilitas Montreal Cognitive Assessment versi Indonesia (MoCA-Ina) untuk skrining gangguan fungsi kognitif. Neurona. 2010;27(4):15- 21.

10. Herman T, Giladi N, Hausdorff JM. Properties of the 'timed up and go'test: more than meets the eye. Gerontology. 2011;57(3):203-10.

11. Koski L, Xie H, Finch L. Measuring cognition in a geriatric outpatient clinic: Rasch analysis of the Montreal Cognitive Assessment. J Geriatr Psychiatry Neurol. 2009;22(3):151- 60 .

12. Li F, Harmer P, Fisher KJ, McAuley E, Chaumeton N, Eckstrom E, et al. Tai Chi and fall reductions in older adults: a randomized controlled trial. J Gerontol A
Biol Sci Med Sci. 2005;60(2):187- 94.

13. Geake JG. The neurological basis of intelligence: A contrast with 'brainbased' education. EDUCATIOn-Line [Online Journal] 2006 [cited 2015 Jan 14]. Available from: http://www.leeds.ac.uk/ educol/documents/156074.htm.

14. Tsang WW, Hui-Chan CW. Effects of exercise on joint sense and balance in elderly men: Tai Chi versus golf. Med Sci Sports Exerc. 2004;36(4):658- 67.

15. Zhang C, Sun W, Yu B, Song Q, Mao D. Effects of exercise on ankle proprioception in adult women during 16 weeks of training and eight weeks of detraining. Res Sports Med. 2015;23(1):102-13.

16. Taylor-Piliae RE, Newell KA, Cherin R, Lee MJ, King AC, Haskell WL. Effects of Tai Chi and Western exercise on physical and cognitive functioning in healthy community-dwelling older adults. J Aging Phys Act. 2010;18(3):261- 79.

17. Doerflinger DMC. Mental status assessment in older adults: Montreal Cognitive Assessment: MoCA version 7.1 (original version). try this: Best Practices in Nursing Care to Older Adults. New York: The Hartford Institute for Geriatric Nursing, New York University, College of Nursing; 2012. p.1. 